\title{
A review of the seismotectonics of the Makran Subduction Zone as a baseline for Tsunami Hazard Assessments
}

\author{
Mohammad Mokhtari* ${ }^{*}$, Ahmad Ala Amjadi, Leila Mahshadnia and Mandana Rafizadeh
}

\begin{abstract}
The Makran Accretionary Wedge (900 km across) is a consequence of northward subduction of the oceanic part of the Arabian Plate beneath the Lut and Afghan blocks in the northwestern Indian Ocean. It has a complicated tectonic setting as it is located at a triple junction with the Indian Plate. Thick sedimentary layers, a shallow angle of the subducting slab and a large width of the subduction zone, ca. 500-600 km from volcanic arc to active wedge front, are some of the foremost and distinctive characteristics of the Makran Subduction Zone (MSZ). The MSZ is likely divided into at least two segments: the west and the east possibly separated by a sinistral fault known as the Sonne Fault. A division is also inferred from seismicity as it is higher in the east when compared to the west. With the exception of a notable trench, all other characteristics of an accretionary prism observed in well-studied subduction zone can be identified or inferred in the Makran. Three long seismic profiles of the western Makran (200 km long each, with shot points interval of $20 \mathrm{~km}$ and receivers interval of $700 \mathrm{~m}$ ) have recently been acquired. Using these datasets, improved structural/velocity models for the western Makran were developed. This review aims to contribute to achieving a better understanding of the seismotectonic setting and dynamics of the Makran Subduction Zone as it feeds to a refined understanding of the tsunami hazard in the region.
\end{abstract}

Keywords: Makran, Tsunami, Oman Sea, Reflection data, Subduction zone, Tsunami Early Warring

\section{Introduction}

A subduction zone along the Makran coasts that forms the boundary between the Arabian and Eurasian Plates was first noted by Stoneley (1974). Later, foundation work by Shearman (1977) and Farhoudi and Karig (1977) followed by others such as Page et al. (1979) used field surveys of the Iranian coastline, air photo analysis, and aerial reconnaissance, to confirm the existence of a subduction zone and build a tectonic model to characterize the modern Makran Subduction Zone (MSZ).

Together with the onshore Makran Ranges, the MSZ has one of the largest accretionary wedges on the earth at approximately $900 \mathrm{~km}$ across. It is characterized by a high sediment thickness of about $7 \mathrm{~km}$ as reported by Byrne et al. (1992), Kopp et al. (2000) and Mokhtari (2014).

\footnotetext{
${ }^{*}$ Correspondence: mokhtari@iiees.ac.ir

National Center for Earthquake Prediction, International Institute

of Earthquake Engineering and Seismology (IIEES), Tehran, Iran
}

The Makran Accretionary Wedge in the northwestern Indian Ocean is a consequence of northward subduction of the oceanic part of the Arabian Plate beneath the Lut and Afghan blocks (the Eurasian plate). The region has a complicated tectonic setting located at a triple junction with the Indian Plate (Fig. 1).

Thick sedimentary layers, a shallow angle of the subducting slab and a large width of the subduction zone, ca. 500-600 km from volcanic arc to active wedge front, are some of the distinctive features of the MSZ (Mokhtari et al. 2008; Mokhtari 2014; Heidarzadeh et al. 2008a, b; Smit et al. 2010). The MSZ appears to be divided into at least two segments: the west and the east possibly separated by a sinistral fault known as the Sonne Fault (Fig. 1). This was supported by Kukowski et al. (2000) who introduced a new boundary aligned with the Sonne strike-slip fault.

Additional work based on geomorphological and seismological observations onshore also suggest that 


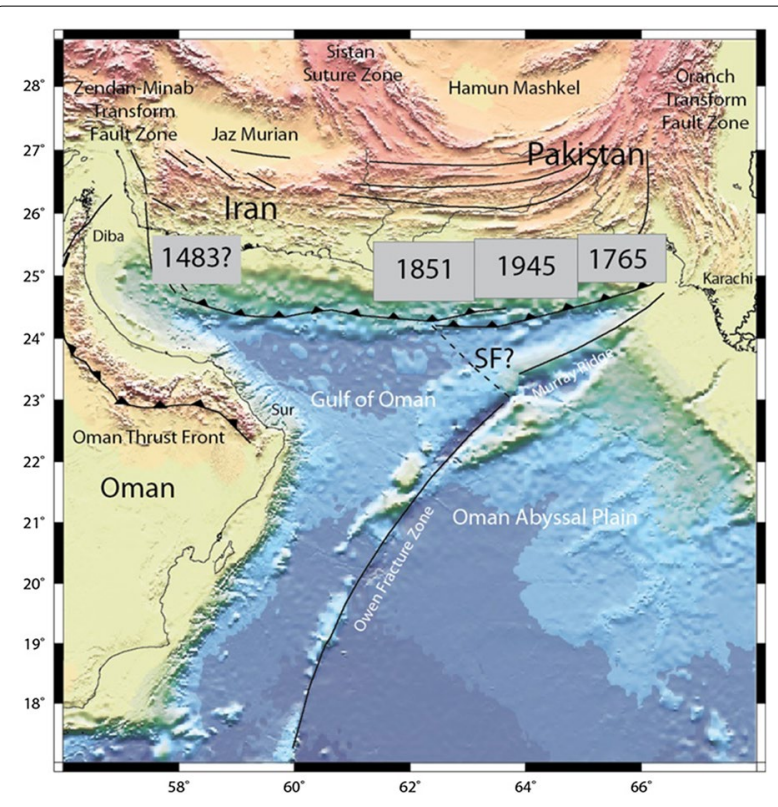

Fig. 1 Main structural setting of the Makran Subduction Zone area. Ruptured area of strong historical earthquakes in Makran based on Byrne et al. (1992) and Okal and Synolakis (2008). SF: Sonne Fault, defining a small microplate boundary, called Ormara microplate by Kukowski et al. (2000)

the subduction zone is likely to consist of two different domains located east and west of the Sistan Suture Zone, a structure that is the continuation of the Sonne Fault system located offshore (Byrne et al. 1992; Kukowski et al. 2000; Okal and Synolakis 2008; Heidarzadeh et al. 2009).

Regarding seismicity, several tsunamigenic earthquake events have occurred in historical times in 1756 and 1851 in the east and 1483 in the west. It is immediately important to mention that the location of 1483 event has been associated with the Strait of Hormuz by several authors, notably Musson (2009) and Rajendran et al. (2013). The most recent large tsunami event occurred on 27 November 1945 associated with an earthquake of magnitude 8.1 in the east Makran. It caused about 4000 casualties along the Makran coast affecting Iran, Pakistan, Oman and the United Arab Emirates (Heck 1947).

Since 1945 both coastal population and economic growth surrounding the Makran region have been increasing very rapidly and the vulnerability of these communities underscores the necessity for the development of Tsunami Hazard Assessments as an essential part of the development process. There has been considerable effort put into tsunami modeling for the MSZ using mainly the 1945 tsunami (e.g., Heidarzadeh et al. 2008a, b; Okal and Synolakis 2008; Burbidge et al. 2009). Such models are used as the basis for tsunami Early
Warning System and preparedness; however, there are issues with these models that are primarily concerned with the source input parameters. As such, there are major ongoing efforts being conducted to acquire data onshore and offshore to improve the understanding of geophysical and source parameters. Such efforts will likely assist in the formation of tsunami assessments that have higher accuracy.

In this paper, after reviewing the seismicity of the Makran region, the seismotectonic framework of the area is addressed. Thereafter, the seismic expression of the Makran offshore zone in the east and west will be compared and contrasted. Finally, a preliminary Tsunami Hazard Assessment is provided along with an outline for a Tsunami Early Warning System and future planned work.

\section{Seismicity}

The MSZ is unique due to its geological and seismological characteristics. It shows relatively low seismicity in comparison other subduction zones worldwide (Mokhtari et al. 2008; Heidarzadeh et al. 2008a, b). Despite the relatively low seismicity, several tsunamigenic events have been reported in the MSZ. Moderate magnitude earthquakes on the western section of the Makran were believed to have occurred in 1008 and 1483, the latter associated with the Strait of Hormuz and probably not on the subduction mega-thrust (Musson 2009; Rajendran et al. 2013). According to Murty and Bapat (1999), a tsunami was observed in the northern Indian Ocean on the southern coast of Iran from a local earthquake in 1008. Ambraseys and Melville (1982) discussed this event in more detail and reported that the earthquake and tsunami sunk some ships and killed a large number of people (there is no information on the actual numbers). It has been reported by Rastogi and Jaiswal (2006) that the epicenter of the earthquake was likely near $25.01 \mathrm{~N}$ and 60.01E in the western Makran Subduction Zone.

In contrast, several significant events have been reported along the eastern part of MSZ, including earthquakes in 1756, 1851 and 1945 (Fig. 1). The $1945 \mathrm{Mw} 8.1$ earthquake is by far the largest instrumentally recorded earthquake in the area (Byrne et al. 1992). The rate of seismicity in the westernmost of the 1945 earthquake ruptured zone is inferred to be higher than the east Makran (Quittmeyer and Jacob 1979). This area overlaps with the easternmost of the rupture zone of the 1851 earthquake and there is speculation about the recurrence of a future earthquake in this area (e.g., Byrne et al. 1992; Pararas-Carayannis 2006).

The onshore and offshore seismicity of the Markran from 1929 till 2018 is plotted in Fig. 2. The map highlights the fact that the seismicity increases from 1929 to 


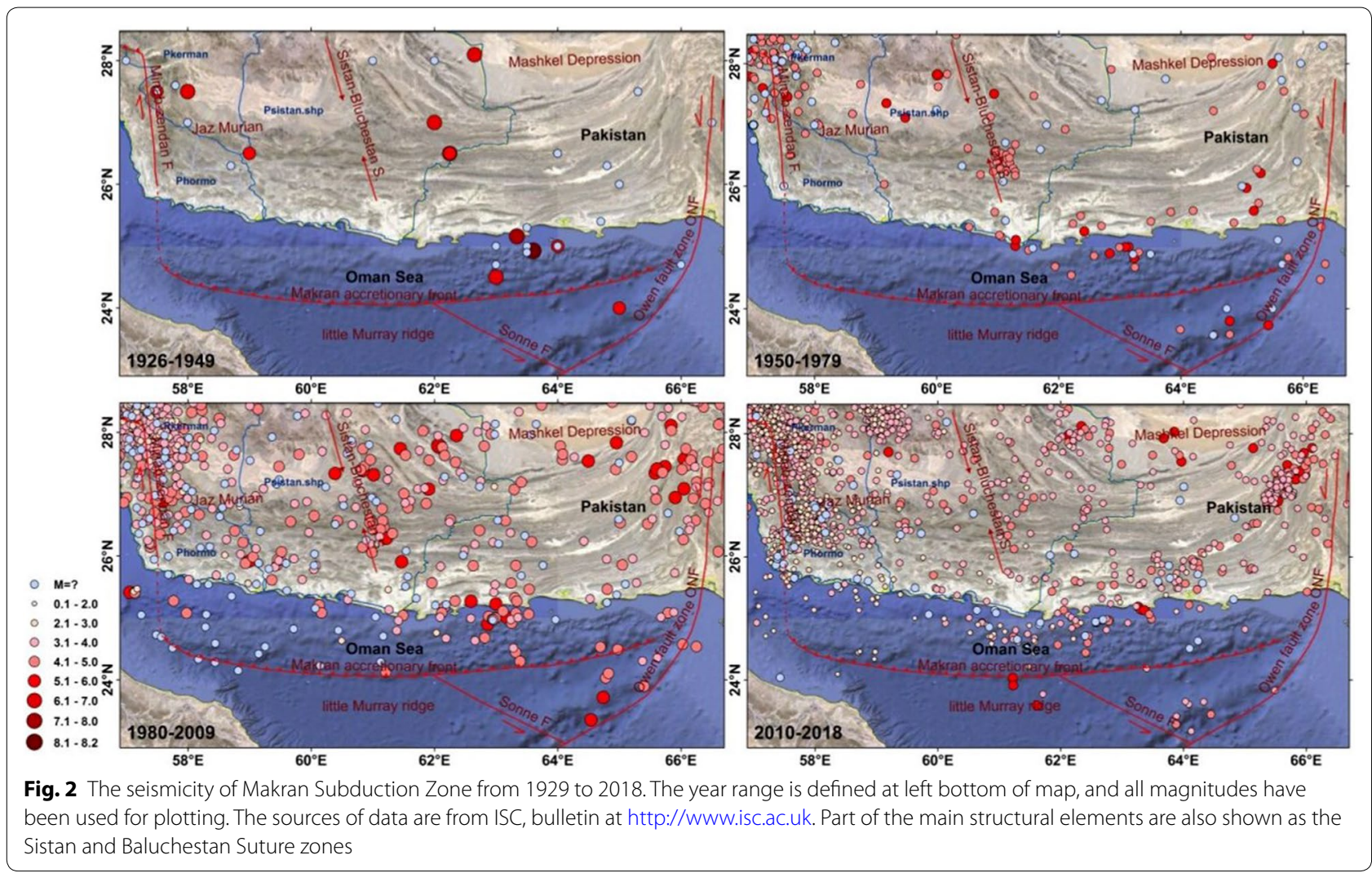

2018. The two moderate earthquake events of 5.2 and 5.3 offshore Oman are noticeable in Fig. 2. Although the causative fault for the generation of the above-mentioned earthquakes has not yet been determined. An apparent increase of seismicity in the eastern Makran has been noted but it is important to consider that it is likely that the lower seismic events are not recorded due to unavailability of seismic stations in the area. This is now largely addressed by the new agreement between Iran and Oman where they share on-line seismic data from their network bilaterally.

It is important to mention some large onshore seismic events that have been reported including the September 2013 Balochistan earthquake with magnitude of $7.7(\mathrm{Mw})$. This event occurred at the eastern end of the Makran accretionary prism on the Hoshab branch at the southern end of the Chaman-Oranch Fault System. The Hoshab Fault is curved, and the sense of motion was leftlateral strike-slip along the entire $200 \mathrm{~km}$ rupture length (Avouac et al. 2014). Avouac et al. (2014) proposed that the southern part of the Makran accretionary prism is being extruded to the east favoring strike-slip motion on the Hoshab fault. GPS velocities collected south of the Hoshab Fault show N-S compression of $\sim 10 \mathrm{~mm} /$ year across the region of the fault (Frohling and Szeliga 2016). Such earthquakes accommodate pure shear with the regional shortening by strike-slip faulting, without requiring the sense of slip changes between earthquakes. It is noticeable that the accretionary wedge overlying the subducting slab is likely undergoing active deformation as exemplified by $2013 \mathrm{Mw} 7.7$ earthquake (Jolivet et al. 2014). After the September 2013 event, a tsunami most likely caused by a landslide (Baptista et al. 2014; Heidarzadeh and Satake 2014; Hoffmann et al. 2015) was recorded along the coast of Oman (Fig. 3).

The shallow earthquakes in the Makran show clear spatial variations in the style of strain. Shallow thrust earthquakes occur offshore or near the coast, and most onshore earthquakes at the lateral edges of the prism are strike-slip. Three strike-slip earthquakes, and an isolated thrust event, are the only examples of shallow $(<15 \mathrm{~km})$ seismic deformation in the central part of the onshore accretionary prism (Penney et al. 2017). Figure 4 shows all the earthquakes, $\mathrm{mb}>4$, from 1945 to 2013 with focal mechanisms reported by CMT or in the literature (Penney et al. 2017).

Lin et al. (2015) inferred the distribution of inter-seismic coupling on the eastern Makran mega-thrust from 2003 to 2010. They found high inter-seismic coupling (i.e., the mega-thrust does not slip and elastic strain accumulates) in the central section of eastern Makran, where the 1945 earthquake occurred, while lower coupling 


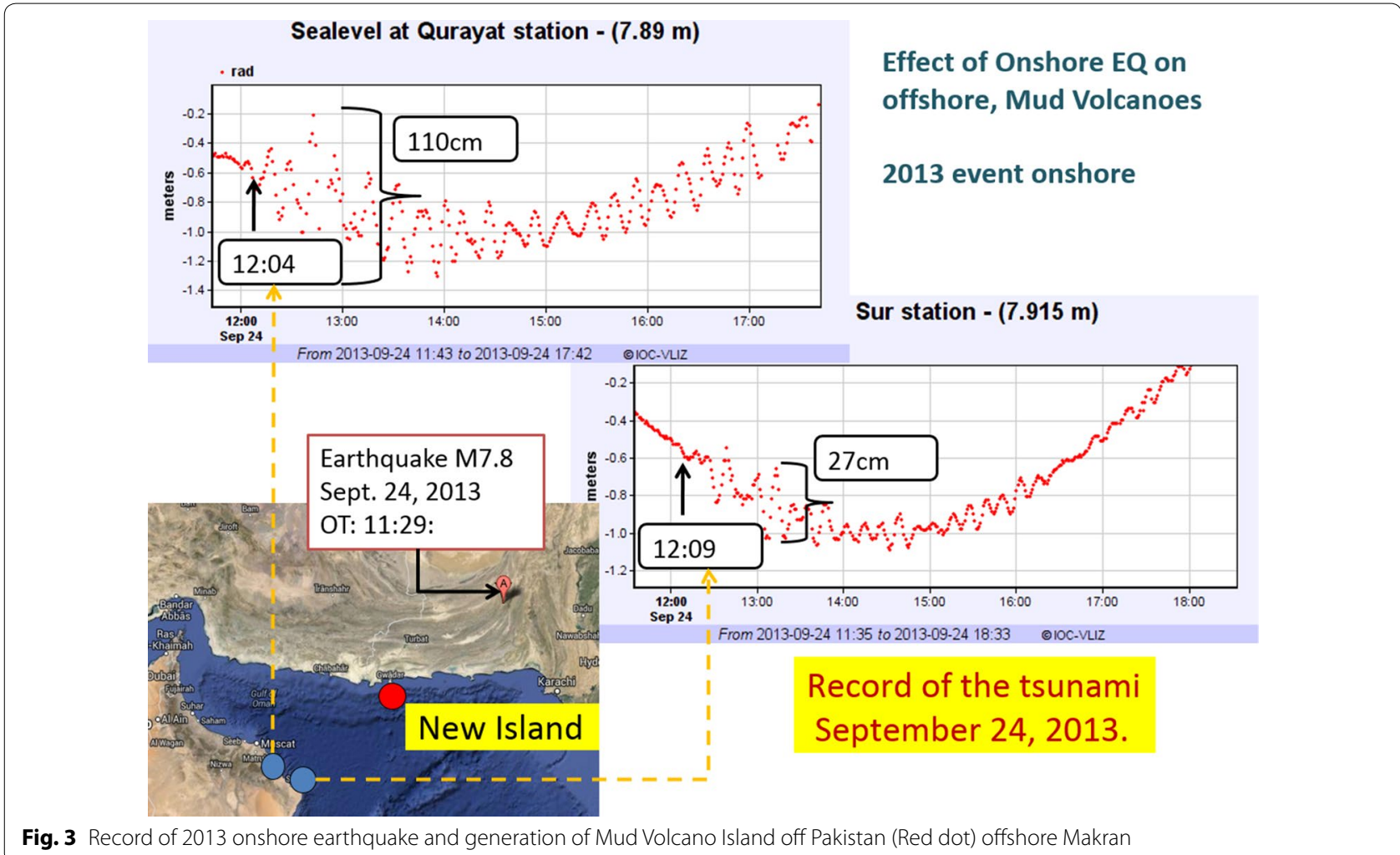

Fig. 3 Record of 2013 onshore earthquake and generation of Mud Volcano Island off Pakistan (Red dot) offshore Makran

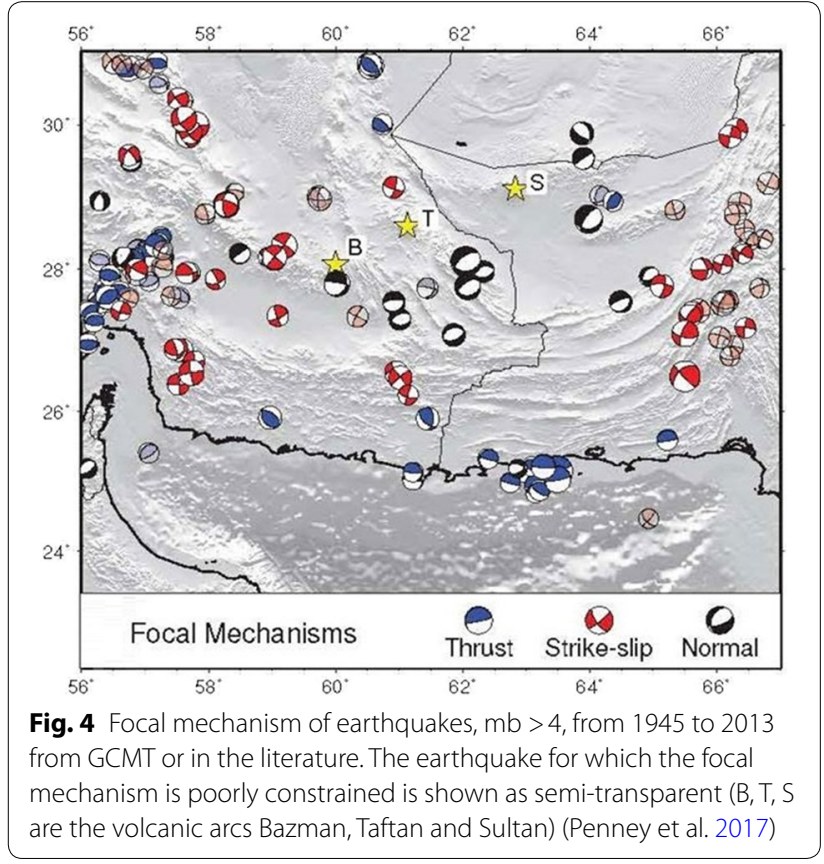

coincides spatially with the subduction of the Sonne Fault Zone. The inferred accumulation of elastic strain since the 1945 earthquake may imply the future occurrence of magnitude 7+ earthquakes and could not exclude the possibility of a multi-segment rupture that would likely exceed Mw 8. These data suggest high fault coupling in the area where a magnitude 8.1 tsunamigenic earthquake ruptured 73 years ago. Lin et al. (2015) ruled out models where the interface is fully creeping as well as models where coupling is homogeneously distributed down to 20-30 km depth.

\section{Seismotectonic framework}

Based on tectonic reconstructions, it is suggested that subduction in the MSZ was initiated in the Late Cretaceous (e.g., Berberian et al. 1982; McCall and Kidd 1982; McCall 2002). The sedimentary hanging wall of the main décollement is folded and imbricated in the modern accretionary prism (e.g., White and Louden 1982; Ellouz-Zimmermann et al. 2007b; Grando and McClay 2007) and the accretionary wedge likely developed in the offshore region since the Early-Middle Miocene. The MSZ is characterized by a typical thrustand-fold belt with forward propagation of thrusting, sediment underplating at the front and subsequent thickening and uplifting the accretionary complex (Kopp et al. 2000; Schlüter et al. 2002; Ellouz-Zimmermann et al. 2007a, b). This submarine wedge has been documented using conventional deep seismic reflection 


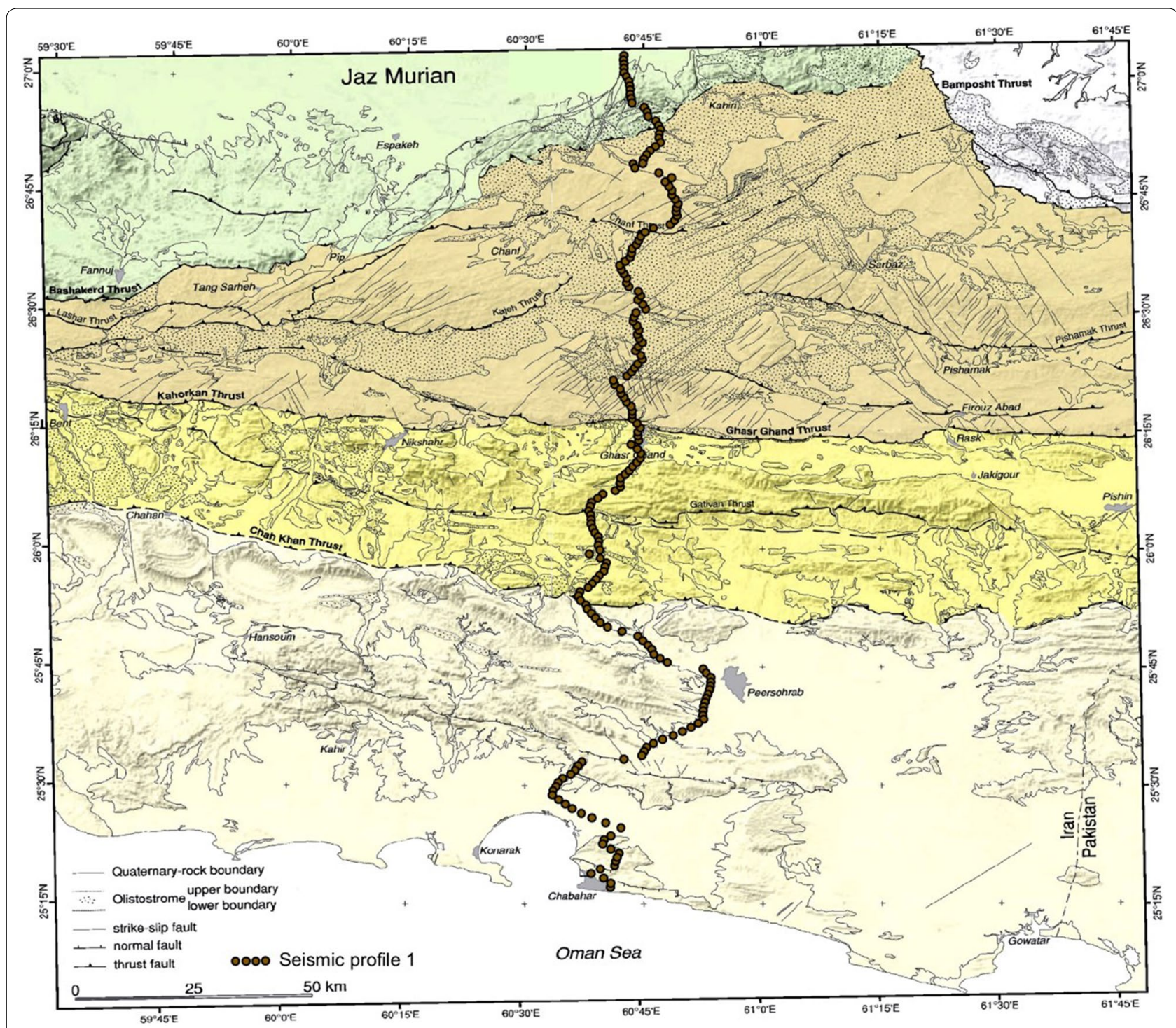

Fig. 5 Simplified geological map of the onshore East Makran with main thrusts separating the four principal litho-tectonic units (Burg et al. 2012). The location of the recently acquired active seismic profile is also shown

data both east and west of offshore Makran (EllouzZimmermann et al. 2007b; Grando and McClay 2007; Mokhtari et al. 2008). The Makran Accretionary Wedge exposed in Iran was a progressively filled basin dominated by turbidites of Middle Eocene and Middle Miocene age (Burg et al. 2012). Five main thrust sheets are separated by major thrusts. From north to south they are North, Inner, Outer, coastal and offshore including the abyssal plain Makran (Figs. 5 and 6).

Unlike other subduction zones, globally there is no trench in the MSZ (Schluter et al. 2002; Mokhtari et al. 2008). Oceanic trenches are the direct manifestation of underthrusting oceanic lithosphere and are developed on the oceanic side of subduction zones with depths of about 2-4 km below the surrounding Ocean Floor (Kearey and Vine 1996).

Seismic profiles also document large normal fault systems near the coast, which are also found on land in the Coastal plain area (Dolati 2010). Volcanic arcs were thought to form approximately $100 \mathrm{~km}$ above the contour of subducting slabs (Davis et al. 1983) but significant variations have been found (e.g., England et al. 2004; Syracuse and Abers 2006). This is probably due to the dependence of thermal structure on convergence rate, plate dip and age (England and Wilkins 2004). Penney et al. (2017) proposed that the hinge line lies just south 


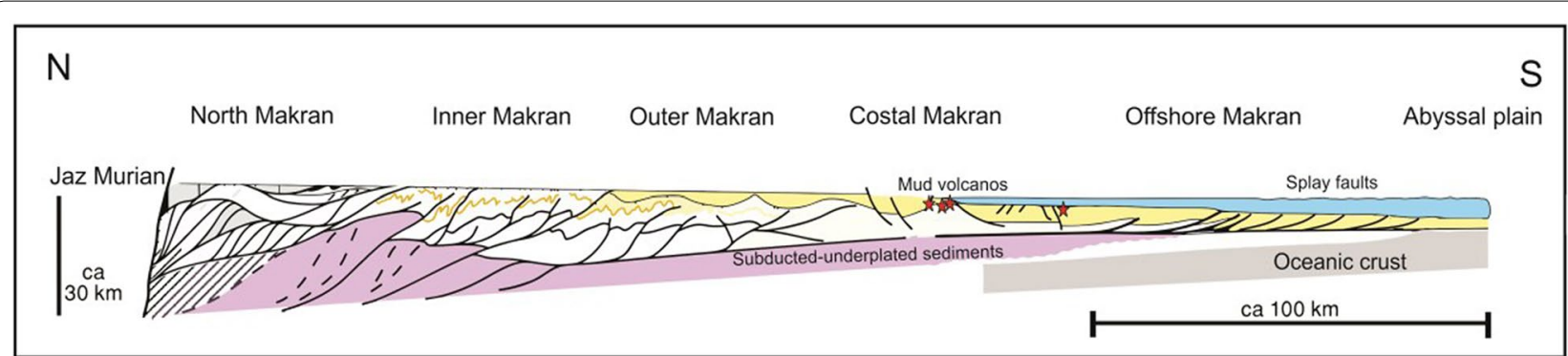

Fig. 6 A North-South cross section based on the data available in the region, both onshore fold and thrust and offshore Makran Accretionary Wedge (modified after Burg et al. (2012))

of the volcanic arc in the Makran. This arc is composed of three main volcanic centers (yellow stars in Fig. 4), which have chemical signatures indicative of subduction volcanism (Biabangard and Moradian 2008; Nicholson et al. 2010; Saadat and Stern 2011). Earthquakes deeper than the proposed hinge line have only been recorded in the east with the exception of an isolated deep event in the far west, reported by Maggi et al. (2000). However, one of the normal-faulting earthquakes occurred almost directly beneath Bazman volcano, at a depth of $74 \mathrm{~km}$ (Jacob and Quittmeyer 1979). This suggests the subduction interface is not deeper than $\sim 80 \mathrm{~km}$ under this part of the volcanic arc, allowing for $\sim 5 \mathrm{~km}$ possible error in the earthquake depth. For the subduction interface to reach a depth of $\sim 100 \mathrm{~km}$ by the latitudes of Taftan and Sultan (at $62^{\circ} \mathrm{E}$ ) it would need to significantly increase its dip north of the line of normal-faulting earthquakes. As the earthquakes likely occur within the descending slab and are related to normal-faulting, they provide an upper limit on the average dip of the subduction interface in the region.

Penney et al. (2017) suggest overall convergence rates of $20.4 \mathrm{~mm} /$ year and $32.6 \mathrm{~mm} /$ year in the west and east of $59.5 \mathrm{E}$, respectively, based on surface velocity from a coupling model with a locking depth of $30 \mathrm{~km}$, mean dip of $11^{\circ}$. However, earlier studies that employed a network of 27 GPS (Global Position System) in Iran and Northern Oman reveal that the subduction rate at the Makran zone is about 19.5-27 mm/year (Vernant et al. 2004). Another study based on the GPS measurement by Masson et al. (2005) inferred a subduction rate of about $18 \mathrm{~mm}$ /year. When compared with other subduction zones in other parts of the world, this value is considerably lower, for example, in Aleutians, it is about $60-70 \mathrm{~mm} /$ year; in Sumatra, about $70 \mathrm{~mm}$ /year; in Kamchatka, about 75-78 $\mathrm{mm} /$ year; in Chile, about $80 \mathrm{~mm} /$ year; in Japan, about $90 \mathrm{~mm} /$ year and in Tonga, it is about $165 \mathrm{~mm} /$ year (Gorbatov and Kostoglodov 1997).

\section{Seismic expression of the subduction zone}

National Iranian Oil Company has acquired 17,000 km 2D seismic data covering the Oman Sea (only east part) in both North-South and East-West directions in 2000. In this package, three seismic profiles were shot with the record-length of $20 \mathrm{~s}$ in North-South direction. Similarly, 2D seismic reflection and refraction data were acquired from the western Makran (Kopp et al. 2000). Figure 7a shows the offshore depth migrated, seismic reflection profile in the western side of the Makran and its associated interpretation as line drawing in the lower panel [see for location Fig. 7c, from Kopp et al. (2000)]. This should be compared to the time-migrated, seismic reflection profile in the Eastern side where its interpretation has been superimposed as line drawing on the seismic section [Fig. 7b, see for location Fig. 7c, Mokhtari (2014)]. Both sections indicate the major folded and thrusted deformation to the south in front of the accretionary prism and in the same region toward the north there are several splay faults. In the northern parts of the sections, some thrust-related Mud Volcanoes have also been identified (Figs. 6, 7a, b).

As it can be seen in the above-mentioned figures, despite the difference in the rate of seismicity in east and west Makran, the main structural elements are very similar. For example, both areas have a northward dipping thrust pack that is easily detectable within the accretionary prism. Also, southward converging reflectors beneath the abyssal plain are identified representing north side dipping geometry of the underlying oceanic crust.

\section{Recent seismic data and essence of hazard assessment}

Recently, three active seismic profiles have been acquired onshore in east Makran. Each profile was about $200 \mathrm{~km}$ long, with shot-point interval of $20 \mathrm{~km}$ and the receiver interval of $700 \mathrm{~m}$. Figure 8 shows an example of the shotgather along one of the profiles. These data are being analyzed in a joint effort between IIEES and GFZ. However, 


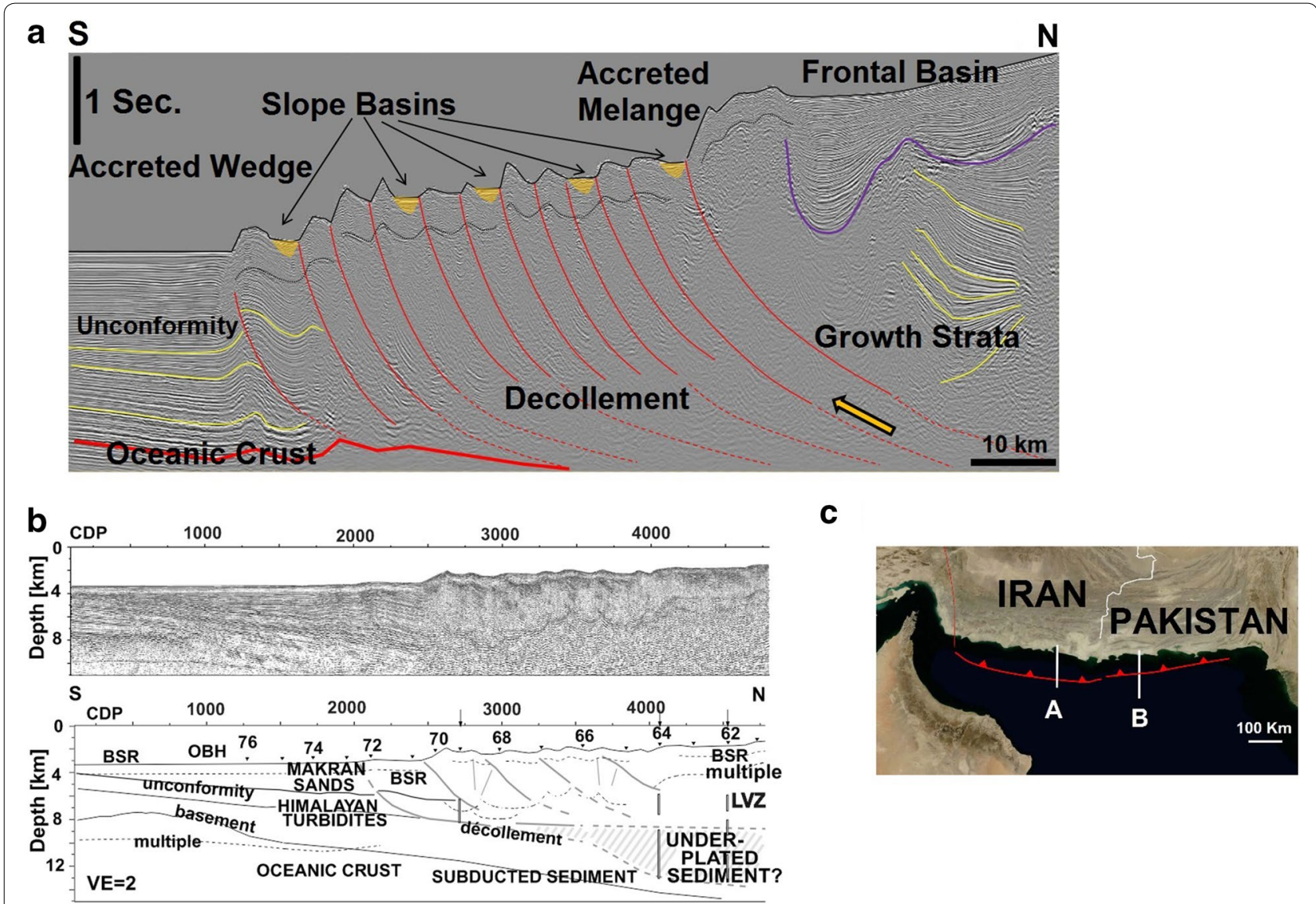

Fig. 7 a The offshore seismic reflection profile on the Iranian side of the Makran and the interpretation is superimposed as the line drawing on the seismic section. The yellow arrow indicates the displacement direction [modified after Mokhtari et al. (2008)]. b The offshore seismic reflection profile in the Pakistani side of the Makran and its interpretation as the line drawing below [from Kopp et al. (2000)]. c The location of both seismic profiles shown on the index map

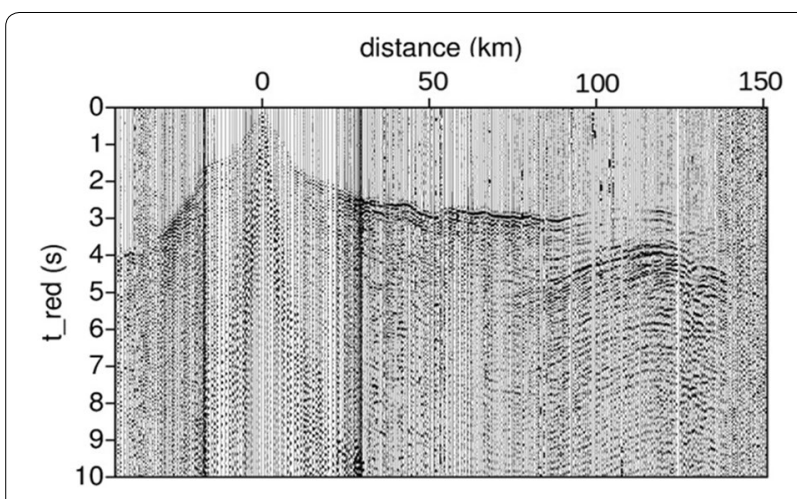

Fig. 8 A shot gathered on onshore Makran. The crustal phase Pg can be observed up to $130 \mathrm{~km}$. Note the strong overcritical reflections (Px) from 80 to $140 \mathrm{~km}$. $Y$-axis is reduced time $\left({ }_{\mathrm{rred}}=6 \mathrm{~km} / \mathrm{s}\right)$; processing included only band pass filtering $(2-10 \mathrm{~Hz})$ and trace balancing it is important to mention that the acquired data quality with high signal to noise ratio and resolution is exclusively valuable.

In an effective Tsunami Hazard Assessment in any particular region, the historical records of tsunami occurrences and the potential for tsunami generation should be evaluated considering the potential seismic parameters of the source.

Based on tsunami modeling and allowing for the uncertainty of the seismic parameters of 1945 earthquake, in the Makran region using different earthquake scenarios it has been found that any probable tsunami in the Makran will likely hit the nearest coastline within about 15 to $20 \mathrm{~min}$. This suggests an element of urgency for the establishment of a clear education system for what coastal communities should do if they feel and earthquake along with parallel efforts to establish an effective tsunami early warning system in the region. Such earthquakes and associated tsunamis present a significant hazard to populations around the Arabian Sea. 


\section{Conclusions and recommendations}

Tsunamis are infrequent but devastating events. The tsunami threat faced by Indian Ocean countries in general and Makran in particular consists of the compound threat of tsunamis from local, regional and distant sources. The main conclusions and suggestions that should be considered are as follows:

- The evolution and deformation history of the accretionary complex is the result of a continuous process, not a series of separate events, so it is important to study both onshore and offshore Makran.

- The seismicity varies significantly between east and west Makran, but, in general, both sides have the capability of generating large earthquakes $8+(\mathrm{Mw})$, which may result in large near-field tsunamis.

- In an effort for tsunami risk reduction, improving our knowledge of the past earthquakes and tsunami occurrence in the region is highly required; therefore, in this respect, more details on Paleo-tsunami studies should be conducted in the future. It is vital to generate more realistic Probabilistic Tsunami Hazard Assessments (PTHA) for the region and the affected countries. Improved hazard assessments may allow the optimization of Early Warning Systems and the development of realistic preparedness strategies in national and local levels. Such efforts should be done in parallel with an education program for what to do when coastal communities feel an earthquake.

- The Mud Volcanoes, both onshore and offshore, can be considered as another factor of risk enhancement. Mapping these features and understanding their generation can also play a vital role in tsunami risk reduction in the region.

- The acquired active seismic refraction and wideangle reflection onshore profiles have shown a turning point in better understanding of seismotectonics in the area; it is important to complement these data with long seismic profiles offshore for better understanding of the source location and its parameters.

\footnotetext{
Acknowledgements

This research was supported by the National Center for Earthquake Prediction International Institute of Earthquake Engineering and Seismology (IIEES), under the Project: Makran study which is in cooperation with the Institute of Geoscience in Germany (GFZ). The major financial support for active seismic data acquisition was supported by Iranian Planning and Budget Organization (PBO).
}

\section{Authors' contributions}

MM conducted the data analysis and solutions, and wrote the major portion of the manuscript. AAA, LM and MR have done the seismotectonic part and helped with figures and writing of the manuscript. All authors read and approved the final manuscript.
Funding

Funding was provided by Makran National Mega Project at IIEES (Grant no. 345347).

Availability of data and materials

Not applicable.

\section{Competing interests}

The authors declare that they have no competing interests.

Received: 1 March 2018 Accepted: 1 November 2019

Published online: 11 November 2019

\section{References}

Ambraseys N, Melville C (1982) A history of Persian earthquakes. Cambridge University Press, New York

Avouac J-P, Ayoub F, Wei S, Ampuero J-P, Meng L, Leprince S, Jolivet R, Duputel Z, Helmberger D (2014) The 2013, Mw 7.7 Balochistan earthquake, energetic strike-slip reactivation of a thrust fault. EPSL 391:128-134

Baptista MA, Omira R, Miranda JM, El Hussain I, Deif A, Habsi Z A (2014) On the source of the 24 September 2013 tsunami in Oman Sea. In: EGU General Assembly Conference Abstracts, vol. 16, p. 6185

Berberian F, Muir ID, Pankhurst RJ, Berberian M (1982) Late Cretaceous and early Miocene Andean-type plutonic activity in northern Makran and Central Iran. J Geol Soc London 139:605-614

Biabangard H, Moradian A (2008) Geology and geochemical evaluation of Taftan Volcano, Sistan and Baluchestan Province, southeast of Iran. Chin J Geochem 27(4):356-369

Burbidge DR, Cummins PR, Mleczko R, Latief H, Mokhtari M, Natawidjaja D, Rajendran CP, Thomas C (2009) A probabilistic Tsunami Hazard Assessment of the Indian Ocean Nations, Geoscience Australia Professional Opinion. No. 2009/11

Burg J-P, Dolati A, Bernoulli D, Smit J (2012) Structural style of the Makran Tertiary accretionary complex in SE-Iran. In: Al Hosani K, Roure F, Ellison $R$, Stephen $L$ (eds) Lithosphere dynamics and sedimentary basins: the Arabian plate and analogues. Frontiers in earth sciences. Springer, Berlin, pp 239-259

Byrne DE, Sykes LR, Davis DM (1992) Great thrust earthquakes and aseismic slip along the plate boundary of the Makran Subduction Zone. J Geophys Res 97(B1):449-478

Davis D, Suppe J, Dahlen FA (1983) Mechanics of fold-and- thrust belts and accretionary wedges. JGR 88(B2):1153-1172

Dolati A (2010) Stratigraphy, structure geology and low-temperature thermochronology Across the Makran Accretionary Wedge in Iran. Ph.D. Thesis, ETH Zurich

Ellouz-Zimmermann N, Deville E, Müller C, Lallemant S, Subhani A, Tabreez A (2007a) Impact of sedimentation on convergent margin tectonics: example of the Makran accretionary prism (Pakistan). Thrust Belts and Foreland Basins, chapter 17. Springer, Berlin, pp 327-350

Ellouz-Zimmermann N, Lallemant SJ, Castilla R, Mouchot N, Leturmy P, Battani A, Buret C, Cherel L, Desaubliaux G, Deville E, Ferrand J, Lugcke A, Mahieux G, Mascle G, Muhr P, Pierson-Wickmann AC, Robion P, Schmitz J, Danish M, Hasany S, Shahzad Tabreez A (2007b) Offshore frontal part of the Makran accretionary prism: the Chamak survey (Pakistan). In: Lacombe O, Roure F, Lave' J, Verges' J (eds) Thrust belts and foreland basins. Frontiers in Earth Sciences. Springer, Berlin, pp 351-366

England P, Wilkins C (2004) A simple analytical approximation to the temperature structure in subduction zones. Geophys J Int 159(3):1138-1154

England P, Engdahl R, Thatcher W (2004) Systematic variation in the depths of slabs beneath arc volcanoes. Geophys J Int 156(2):377-408

Farhoudi G, Karig DE (1977) The Makran of Iran and Pakistan as an Active Arc System. Geology 5(11):664-668

Frohling E, Szeliga W (2016) GPS constraints on interplate locking within the Makran subduction zone. Geophys J Int 205(1):67-76

Gorbatov A, Kostoglodov V (1997) Maximum depth of seismicity and thermal parameter of the subducting slab: general empirical relation and its application. Tectonophysics 277(1-3):165-187

Grando G, McClay K (2007) Morphotectonics domains and structural styles in the Makran accretionary prism, offshore Iran. Sediment Geol 196:157-179 
Heck NH (1947) List of seismic sea wave. B Seismol Soc Am 37(4):269-286 Heidarzadeh M, Satake K (2014) Possible sources of the tsunami observed in the Northwestern Indian Ocean following the 2013 September 24 Mw = 7.7 Pakistan inland earthquake. Geophys. J. Int 199:752-766 Heidarzadeh M, Pirooz MD, Zaker NH, Yalciner AC, Mokhtari M, Esmaeily A (2008a) Historical tsunami in the Makran subduction zone off the southern coasts of Iran and Pakistan and results of numerical modeling. Ocean Eng 35(8 \& 9):774-786

Heidarzadeh M, Pirooz MD, Zaker NH, Synolakis CE (2008b) Evaluating tsunami hazard in the northwestern Indian Ocean. Pure Appl Geophys 165(11-12):2045-2058

Heidarzadeh M, Pirooz MD, Zaker NH, Yalciner AC (2009) Modeling the nearfield effects of the worst possible tsunami in the Makran subduction zone. Ocean Eng 36(5):368-376

Hoffmann G, Grutzner C, Reicherter K, Preusser F (2015) Geo-archaeological evidence for a Holocene extreme flooding event within the Arabian Sea (Ras al Hadd, Oman). Quat Sci Rev 113:123-133

Jacob KH, Quittmeyer RL (1979) The Makran region of Pakistan and Iran: Trench-arc system with active plate subduction. In: Farah A, de Jong KA (eds) Geodynamics of Pakistan. Quetta Geological Survey of Pakistan, Quetta, pp 305-317

Jolivet R, Duputel Z, Riel B, Simons M, Rivera L, Minson SE, Zhang H, Aivazis MAG, Ayoub F, Leprince S, Samsonov S, Motagh M, Fielding EJ (2014) The 2013 Mw 77 Balochistan earthquake: seismic potential of an accretionary wedge. Bull Seismol Soc Am 104(2):1020-1030

Kopp C, Fruehn J, Flueh ER, Reichert C, Kukowski N, Bialas J, Klaeschen D (2000) Structure of the Makran subduction zone from wide-angle and reflection seismic data. Tectonophysics 329:171-191

Kukowski N, Schillhorn T, Flueh ER, Huhn K (2000) Newly identified strike-slip plate boundary in the northeastern Arabian Sea. Geology 28(4):355-358

Lin NY, Jolivet R, Simons M, Agram PS, Martens HR, Li Z, Lodi SH (2015) High interseismic coupling in the Eastern Makran (Pakistan) subduction zone. EPSL 420:116-126

Maggi A, Jackson JA, Priestley K, Baker C (2000) A re-assessment of focal depth distributions in southern Iran, the Tien Shan and northern India: do earthquakes really occur in the continental mantle? Geophys J Int 143(3):629-661

Masson F, Chery J, Hatzfeld D, Martinod J, Vernant P, Tavakoli F, Ghafory-Ashtiani M (2005) Seismic versus aseismic deformation in Iran inferred from earthquake and geodetic data. Geophys J Int 160(1):217-226

McCall GJH (2002) A summary of the geology of the Iranian Makran. In: Clift PD, Kroon FD, Gaedecke C, Craig J (eds) The tectonic and climatic evolution of the Arabian Sea Region, Special Publication, vol 195. Geol Soc, London, pp 147-204

McCall GJH, Kidd RGW (1982) The Makran, Southeastern Iran: the anatomy of a convergent plate margin active from Cretaceous to Present. In: Leggett JK (ed) Trench-fore-arc geology: sedimentation and tectonics of modern and ancient plate margins, Special Publication, vol 10. Geological Society, London, pp 387-397

Mokhtari M (2014) The role of splay faulting in increasing the devastation effect of tsunami hazard in Makran, Oman Sea. Arab J Geosci. https://doi. org/10.1007/s12517-014-1375-1

Mokhtari M, Abdoulahi Fard I, Hessami K (2008) Structural elements of the Makran region, Oman Sea, and their potential relevance to tsunamigenesis. Nat Hazards 47:185-199

Murty TS, Bapat A (1999) Tsunamis on the coastlines of India. Sci Tsunami Hazards 17(3):167-172

Musson RMW (2009) Subduction in the Western Makran: the historian's contribution. J Geol Soc 166(3):387-391

Nicholson KN, Khan M, Mahmood K (2010) Geochemistry of the Chagai-Raskoh arc, Pakistan: complex arc dynamics spanning the Cretaceous to the Quaternary. Lithos 118(3-4):338-348

Okal EA, Synolakis CE (2008) Far-field tsunami hazard from mega-thrust earthquakes in the Indian Ocean. Geophys J Int 172(3):995-1015
Page WD, Alt JN, Cluff LS, Plafker G (1979) Evidence for the recurrence of large magnitude earthquakes along the Makran coast of Iran and Pakistan. Tectonophysics 52:533-547

Pararas-Carayannis G (2006) The potential for tsunami generation along the Makran Subduction Zone in the Northern Arabian Sea. Case study: the earthquake and tsunami of November 28, 1945. Sci Tsunami Hazard 24(5):358-384

Penney C, Tavakoli F, Saadat AR, Nankali HR, Sedighi M, Khorrami F, Sobouti F, Ra Z, Cople A, Jackson J, Priestley K (2017) Megathrust and accretionary wedge properties and behaviour in the Makran subduction zone. In: The international archives of the photogrammetry, remote sensing and spatial information sciences, Volume XLII-4/W4

Quittmeyer RC, Jacob KH (1979) Historical and modem seismicity of Pakistan, Afghanistan, Northwestern India, and Southeastern Iran. Bull Seismol Soc Am 69(3):773-823

Rajendran CP, Rajendran K, Shah-Hosseini M, Beni AN, Nautiyal CM, Andrews $R$ (2013) The hazard potential of the western segment of the Makran subduction zone, northern Arabian Sea. Nat Hazards 65(1):219-239

Rastogi BK, Jaiswal R (2006) A catalog of tsunamis in the Indian Ocean. Sci Tsunami Hazards 25(3):128-143

Saadat S, Stern CR (2011) Petrochemistry and genesis of olivine basalts from small monogenetic parasitic cones of Bazman stratovolcano, Makran arc, southeastern Iran. Lithos 125(1-2):607-619

Schluter HU, Prexl A, Gaedicke C, Roeser H, Reichert C, Meyer H, von Daniels C (2002) The Makran accretionary wedge: sediment thicknesses and ages and the origin of mud volcanoes. Mar Geol 185:219-232

Shearman DJ (1977) The geological evolution of Southern Iran, the report of the Iranian Makran expedition. Geogr J 142:393-410

Smit J, Burg J-P, Dolati A, Sokoutis D (2010) Effects of mass waste events on thrust wedges: analogue experiments and application to the Makran accretionary wedge. Tectonics 29, TC3003

Stoneley R (1974) Evolution of the continental margins bounding a former Tethys. In: Burk CA, Drake CL (eds) The geology of continental margins. Springer, New York, pp 889-903

Syracuse EM, Abers GA (2006) Global compilation of variations in slab depth beneath arc volcanoes and implications. Geochem Geophys Geosyst. https://doi.org/10.1029/2005GC001045

Vernant Ph, Nilforoushan F, Hatzfeld D, Abbasi MR, Vigny C, Masson F, Nankali H, Martinod J, Ashtiani A, Bayer R, Tavakoli F, Chery J (2004) Present-day crustal deformation and plate kinematics in the middle east constrained by GPS measurements in Iran and Northern Oman. Geophys J Int 157:381-398

White RS, Louden KE (1982) The Makran continental margin: structure of a thickly sedimented convergent plate boundary. In: Watkins JS, Drake CL (eds) Studies in continental margin geology, vol 34. Members American Association Petroleum Geologists, Tulsa, pp 499-518

\section{Publisher's Note}

Springer Nature remains neutral with regard to jurisdictional claims in published maps and institutional affiliations.

\section{Submit your manuscript to a SpringerOpen ${ }^{\circ}$ journal and benefit from:}

- Convenient online submission

$\checkmark$ Rigorous peer review

- Open access: articles freely available online

- High visibility within the field

- Retaining the copyright to your article

Submit your next manuscript at springeropen.com 